\title{
Synthesis of Green Silver Nanoparticles from Soybean Seed and its Bioefficacy on Spodoptera litura (F.)
}

\author{
Goutam B. Hosamani $^{1 *}$, R.R. Patil ${ }^{1}$, V.I. Benagi ${ }^{2}$, \\ S.S. Chandrashekhar ${ }^{3}$ and B.S. Nandihali ${ }^{1}$
}
${ }^{1}$ Department of Agricultural Entomology, College of Agriculture, University of Agricultural sciences, Dharwad Karnataka -580005, India
${ }^{2}$ Department of Plant pathology, College of Agriculture, University of Agricultural sciences, Dharwad Karnataka -580005, India
${ }^{3}$ Department of Seed Science and Technology, College of Agriculture, University of Agricultural sciences, Dharwad Karnataka -58005, India

*Corresponding author

\section{A B S T R A C T}

\begin{tabular}{|c|}
\hline Keywords \\
\hline $\begin{array}{l}\text { Green } \\
\text { nanoparticles, } \\
\text { Silver, Particle size } \\
\text { Analyzer, S.litura, } \\
\text { and Soybean seed }\end{array}$ \\
\hline Article Info \\
\hline $\begin{array}{l}\text { Accepted: } \\
15 \text { August } 2019 \\
\text { Available Online: } \\
10 \text { September } 2019\end{array}$ \\
\hline
\end{tabular}

Now a day's nanotechnology has become one of the most promising approaches in pest management. Nanoparticles represent a new generation of environmental remediation technologies that provide cost-effective solution to some of the most challenging insect pests. S.litura (F.) (Lepidoptera: Noctuidae) is a major polyphagous pest of field crops and vegetables, causing severe damage to the plants in all phenological crop stages. The overall objective of this investigation was to look for new control strategy through evaluating the effect of Soya based Ag Nano -particles on the $2^{\text {nd }}$ and $3^{\text {rd }}$ instar larvae of $S$. litura under laboratory conditions. In the present study, we have reported the synthesis of silver green nanoparticles from soybean seed extract by Sunlight exposure method and its influence on S.litura. The synthesized soybean based silver nanoparticles were characterized by UV-Vis spectroscopy and particle size analyser (Nicomp). The result revealed that soybean based $\mathrm{AgNo}_{3}$ nanoparticles had a mean diameter of $87 \mathrm{~nm}$ (PSA).Nano Ag particles were the most effective compounds possessing insecticidal activity. Increased concentration and exposure period enhanced larval mortality. AgNPs caused characteristic symptoms of sluggishness, inactiveness, the larvae refusing to feed resulting in larval mortality.

\section{Introduction}

Nanotechnology is defined as the application of science, engineering and technology to develop novel materials and devices in different fields in the nanorange. For the synthesis of silver nanoparticles, there are multiple processes that one could use. Some of these are the electrochemical method, sonochemical method, microwave-assisted processes and lately green chemistry approach. The synthetic nanoparticles though 
available and effective are toxic and hazardous to the environment and to the user. Green nanoparticles are very important in developing sustainable technologies for the future. Synthesis of nanoparticles by plants is a green chemistry approach that interconnects nanotechnology and biotechnology. Plant extracts are used for bio reduction of metal ions to form nanoparticles. It has been demonstrated that plant metabolites like sugars, terpenoids, polyphenols, alkaloids, phenolic acids and proteins play an important role in reduction of metals ions into nanoparticles and support their subsequent stability. Synthesis of nanoparticles from plant extracts or microorganisms are safe to the environment and the user. Further, they are easily available and possess a broad range of metabolites. The integration of the principles of green chemistry to nanotechnology toward the synthesis of green nanoparticles is a current requirement in pest management (Srikanth et al., 2017).

Spodoptera litura (Lepidoptera: Noctuidae) is a polyphagous pest, invading more than 180 plant species. Nowadays, manmade pesticides have been extensively used for controlling this pest on diverse crops, but have adverse side effects especially the frequency of resistance, mutilation to the environment, pest resurrection and fatal effects on non-target organisms have imposed a shift to more ecofriendly approach for managing this pest. Indiscriminate exploitation of insecticides, multiple generations of insects per annum, year-round availability of host crops contributed to the insecticide resistance of S.litura against almost all the insecticide groups (Kranthi et al., 2002) including the new insecticides like lufenuron (Sudhakaran, 2002).

The adverse effects due to synthetic pesticides on pests and their subsequent impacts to ecological imbalance demands sustainable alternatives.
Synthetic Nano-Ag was effective against $S$. litura larvae (Chakravarthy et al., 2012a). More than half of them relied to nanomaterials prepared through the so-called green synthesis method and nanomaterials synthesized from extracts from plants Beneli (2018) bacteria (Ayano et al., 2014) and even dead insects (Jha and Prasad 2012) have been successfully employed to reduce and stabilize nanoparticles in aqueous suspensions. It is quite difficult and challenging to identify such insecticidal activity in the area of new chemistry. The present investigation was aimed to synthesize and evaluate the insecticidal effect of Soyabean seed based green silver nanoparticles.

\section{Materials and Methods}

soybean seeds (DSb 21) were collected from Main Agricultural Research Station, UAS, Dharwad. Synthesis and characterization of green silver nanoparticles was done in the Green Nanotechnology laboratory, while the bioassay was done in the Post graduate laboratory of the Department of Agricultural Entomology, University of Agricultural Sciences, Dharwad. 10 grams of partially grounded seeds were incubated in $100 \mathrm{ml}$ of millipore water for 2 hours in hot water bath. Finally extract was centrifuged at $9000 \mathrm{rpm}$ for removal of heavy seed debris followed by filtration with Whatman No. 1 filter paper. This resulted in production of milky colour seed extract that was stored at $4^{\circ} \mathrm{C}$ for further use.

\section{Biosynthesis of silver green nanoparticles from soybean seeds}

Protocol of Indrakumar (2016) was followed for synthesis of $\mathrm{AgNp}$ from soybean seed extract. $1 \mathrm{mM}$ aqueous silver nitrate $\left(\mathrm{AgNo}_{3}\right)$ was obtained from Hi Media Laboratory, Mumbai and used as a precursor, soybean seed extract was used as reducing and capping agent for synthesis of silver nanoparticles. 1.0 
$\mathrm{ml}$ of soybean seed extract was added to $10 \mathrm{ml}$ of $1 \mathrm{mM}$ aqueous silver nitrate and taken into $30 \mathrm{ml}$ screw test tube mixed well and exposed to bright sunlight for $3 \mathrm{~h}$. Colour change was observed for the confirming the synthesis of silver nanoparticles (sunlight exposure method).

Further the synthesised soya seed based AgNps were characterized to know the size and other parameters using UV-Visible Spectrophotometer (UV-Vis), Particles Size Analyzer (PSA) NICOMP make.

\section{Maintenance of insect culture}

The egg masses were collected from the field of UAS Dharwad, brought to the laboratory and incubated. On hatching the first instars were released on host plant castor Riccinus communis in the laboratory and reared at $25^{\circ} \mathrm{c}$ - $28^{\circ} \mathrm{c}$ temperature and 70 per cent relative humidity.

\section{Bioassay studies}

The castor leaves dipped (leaf dip method) in green nanoparticles of different concentrations were provided as first feed early in the morning from the first day of both $2^{\text {nd }}$ and third instar and the other two were normal feeds. Complete randomized bock design (CRD) design was used three replications were maintained. Ten larvae were used per replication. Based on instar duration observations were recorded on larval mortality at 24, 48, 72 and 96 Hours after treatment (HAT). Per cent mortality was calculated by using the formula.

Per cent mortality $=$

Number of dead insects $\times 100$

Total number of insects

\section{Statistical analysis}

The results obtained were subjected for statistical analysis (ANOVA) using a completely randomized block design. The mean values of treatments were then subjected to Duncan's Multiple Range Test (DMRT).

\section{Results and Discussion}

\section{Biosynthesis of AgNps from soyabean seed extract}

Synthesized soybean based silver nanoparticles were confirmed by colour changes commencing from colourless to different colours. Within 10 minutes of exposure to sunshine the colour changed from colourless to faint yellow and by 3 hours yellow coloured solution changed to dark orange completely. Further, the same colour was retained. The UV-Vis absorption peak was recorded between 425-435 nm with average particle size of $87 \mathrm{~nm}$ (Fig. 1 and 2). The present study with respect to synthesis is in full conformity with the description of Prasad (2014) who used soybean seed extract for synthesis of silver nanoparticles through magnetic stirring method. He characterized nanoparticles by means of UV-Vis and sharp band scattered at $434 \mathrm{~nm}$ clearly notifying the formation of silver nanoparticles TEM image obtained from green synthesized AgNPs were nearly monodisperse spherical shape and size ranged from $25 \mathrm{~nm}$ to $50 \mathrm{~nm}$. In the present study the size of the particle was $87 \mathrm{~nm}, 425$ nm UV-Vis and agrees with the report of Prasad (2014).

Similarly Indrakumar (2016) used soybean seeds for the synthesis of nanoparticles. Among the three methods he followed Sunlight exposure method was effective in synthesis of stable AgNPs. The UV-Vis absorption peak was recorded between 425$435 \mathrm{~nm}$. The particle size of synthesized 
nanoparticles was below $100 \mathrm{~nm}$ and the shape was spherical as being reported in the present study.

Efficacy of soybean seed based Green AgNp's on second and third instar of S.litura

The chemical, Emmamectin benzoate@ 0.2 $\mathrm{gm} / \mathrm{L}$ was significantly superior to all other treatments and showed cent per cent mortality of $2^{\text {nd }}$ and $3^{\text {rd }}$ instar at $24 \mathrm{hrs}$ and $48 \mathrm{hrs}$ after treatment. However, Precursors, the seed extract and water control did not effect any mortality.

The effect of different concentrations of AgNPs on second instar is presented in Table 1. At 24 hours $10000 \mathrm{ppm}$ was superior to all other treatments $(26.67 \%)$ but on par with $8000 \mathrm{ppm}, 6000 \mathrm{ppm}$ that recorded 26.67 and 23.33 per cent mortality respectively. This was followed by 4000 ppm that recorded 20 per cent. Next best were 2000 ppm and 1000 ppm but were on par to each other with 16.67 per cent mortality. This was followed by 750 and500 ppm which differed significantly from one another effecting 13.33 and 10.00 per cent mortality. Least percent mortality was noticed in $250 \mathrm{ppm}$. At 48 hours $10000 \mathrm{ppm}$ was superior to all other AgNps but for 8000 and 6000 ppm recording 60 per cent, 53.33 per cent mortality. However, least per cent mortality $(20 \%)$ was recorded in $250 \mathrm{ppm}$. At 72 hours 10000 and 8000 ppm gave cent percent mortality but were on par to each other as well with chemical treatment. This was followed by $6000 \mathrm{ppm}$ and $4000 \mathrm{ppm}$ with 96.67 and 86.67 per cent mortality but did not differ among themselves. This was followed by 2000,1000 and $750 \mathrm{ppm}$ with mortality of $80.00,80.00,63.33$ and 53.33 per cent respectively exercising similar effects. Least mortality of $46.67 \%$ was recorded in 250 ppm.
In third instar at 24 HAT 10000 ppm, 8000 ppm, $6000 \mathrm{ppm}$ and $4000 \mathrm{ppm}$ were superior to all other treatments with $20.00,20.00,16.67$ and 16.67 per cent mortality and were on par with each other. Next best was 2000 ppm and 1000 ppm both recording 13.33 per cent mortality and were on par to each other. Lowest mortality was noticed in $750 \mathrm{ppm}$. At 48 hours $10000 \mathrm{ppm}$ and $8000 \mathrm{ppm}$ recorded 46.67 and 43.33 per cent mortality and were superior to all other AgNps but on par to each other. Next best was 6000, 4000, 2000 ppm recording $36.67,36.67$ and 33.33 per cent mortality respectively without differing among themselves. This was followed by 1000,750 and $500 \mathrm{ppm}$ and all behaved similarly. However, least per cent mortality $(10 \%)$ was recorded in $250 \mathrm{ppm}$. At 72 hours $10000 \mathrm{ppm}$ was significantly superior to all other treatments with 76.67 per cent mortality. This was followed by $8000 \mathrm{ppm}, 6000 \mathrm{ppm}$ and $4000 \mathrm{ppm}$ but they differed significantly from one another. Next best were 2000, 1000, $750,500 \mathrm{ppm}$ and were on par to each other. Minimum mortality of 23.33 per cent was produced in $250 \mathrm{ppm}$. At 96 hours $10000 \mathrm{ppm}$ gave cent percent mortality but was on par with chemical treatment but superior to all AgNp treatments. This was followed by 8000 ppm, $6000 \mathrm{ppm}$ and $4000 \mathrm{ppm}$ and differed significantly from one another. This was followed by 2000 and $1000 \mathrm{ppm}$ both recording 82.50 per cent mortality \& but were on par to each other. This was followed by $750 \mathrm{ppm}$ (75.45 \%). Minimum mortality $(56.67 \%)$ was recorded in $250 \mathrm{ppm}$. The use of green soya based AgNPs caused inactiveness, the larvae became sluggish ultimately refusing feed and resulting in larval mortality (Table 2).

At $48 \mathrm{hrs}$ the $\mathrm{AgNp}$ extract on $2^{\text {nd }}$ instar recorded $(20.00 \%-63.33 \%)$ mortality and 46.67- 100 per cent mortality at $72 \mathrm{~h}$ while the $3^{\text {rd }}$ instar larvae recorded mortality rate of $23.33-76.67$ per cent at $72 \mathrm{~h}$ and $56.67 \%-100$ 
$\%$ mortality at 96 hours of exposure. The mortality rate increased as the toxic concentration increased. The present study on use of green AgNPs is strengthened by the report of Kasmara et al., (2017) who reported that Lantana camara nano extracts proved to be more effective in managing S. litura 3rd instar larvae since the observed mortality rate was $3-10 \%$ higher in $24 \mathrm{~h}$ and $13-26 \%$ higher in $48 \mathrm{~h}$ as being reported in the present study both for $2^{\text {nd }}$ and $3^{\text {rd }}$ instar.

Fig.1 UV-Vis spectrum of Silver nanoparticle synthesized by Soybean seed extract

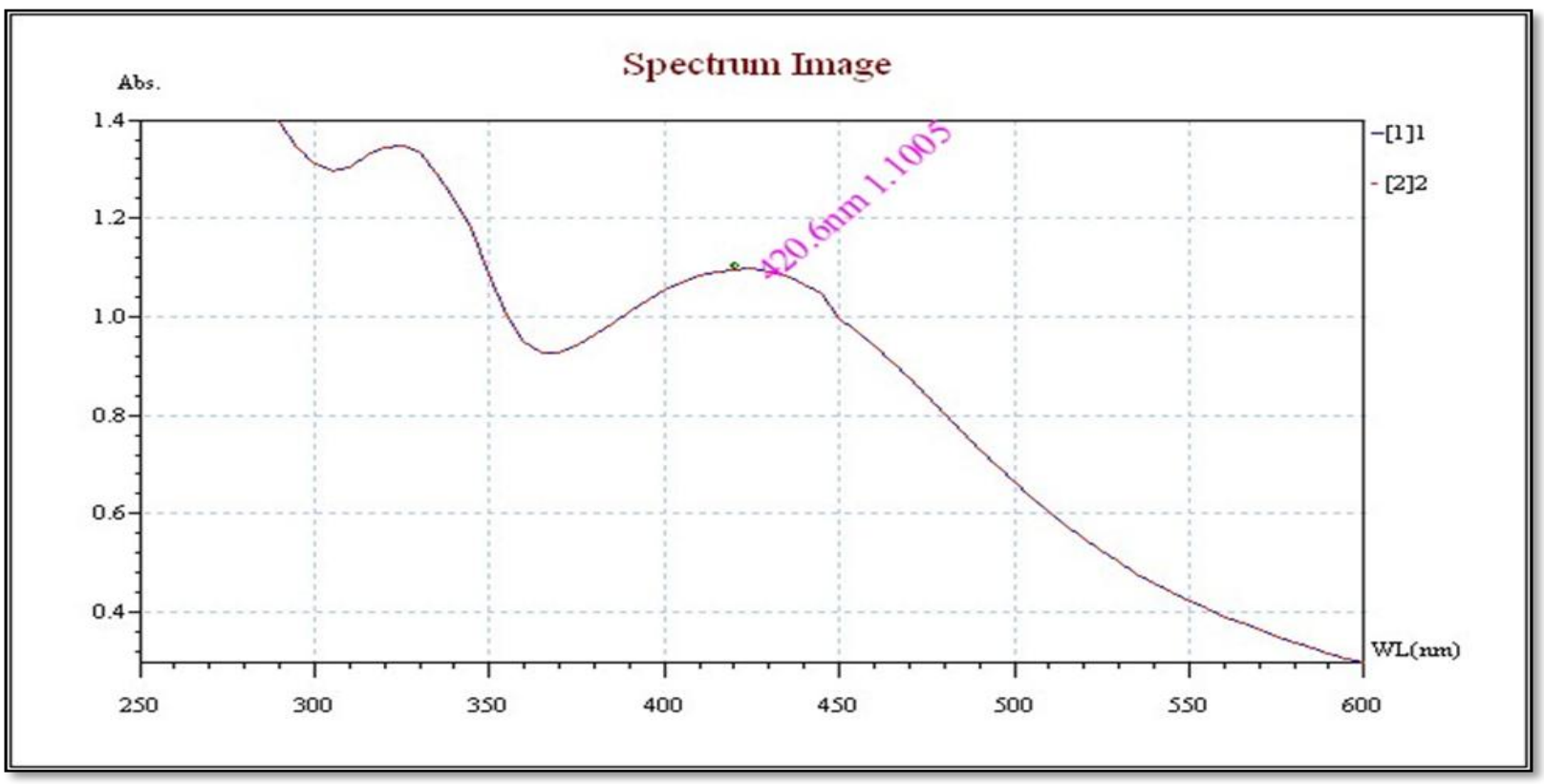

Fig.2 Particle size of Silver nanoparticle synthesized from soybean seed extract of Average Size $87 \mathrm{~nm}$

REL. INTENS-WT GAUSSIAN DISTRIBUTION

100

80

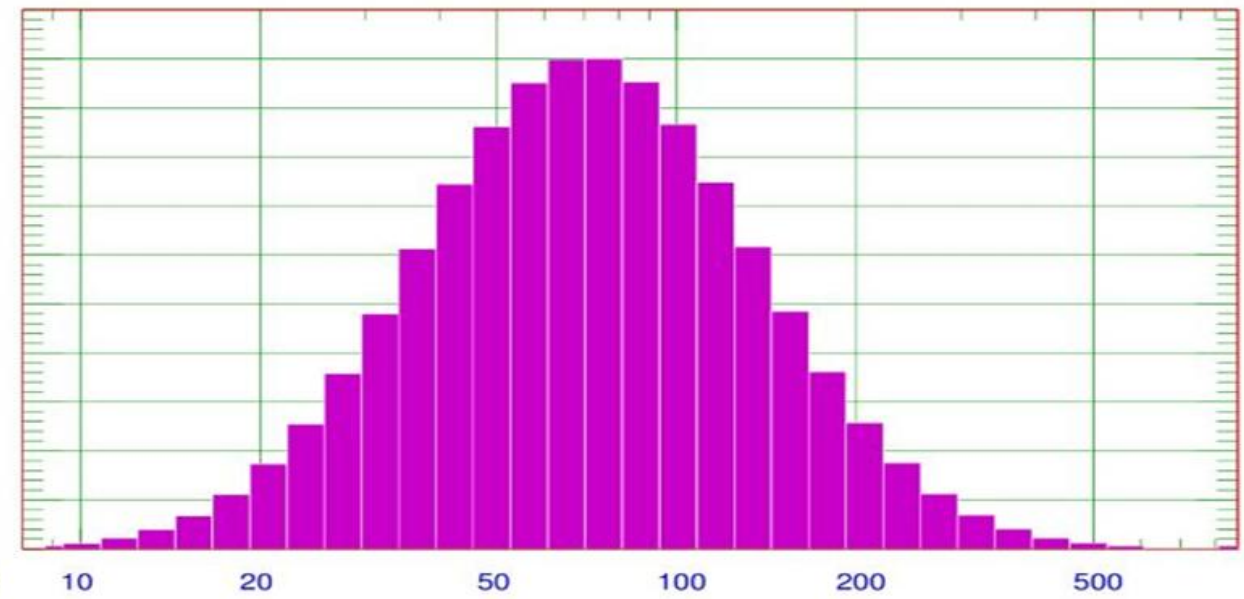

Diam $(\mathrm{nm}) \rightarrow>$ 
Table.1 Effect of Soybean seed based Green Silver nanoparticles on percent larval mortality of S. litura (second instar)

\begin{tabular}{|c|c|c|c|}
\hline \multirow{2}{*}{$\begin{array}{c}\text { Treatments / } \\
\text { Concentrations in ppm }\end{array}$} & \multicolumn{3}{|c|}{ Hours After Treatment (HAT) } \\
\hline & 24 hours & 48 hours & 72 hours \\
\hline 250 & $\begin{array}{c}3.33 \\
(1.91)^{\mathrm{g}}\end{array}$ & $\begin{array}{l}20.00 \\
(7.33)^{\mathrm{f}}\end{array}$ & $\begin{array}{l}46.67 \\
(7.55)^{\mathrm{e}}\end{array}$ \\
\hline 500 & $\begin{array}{l}10.00 \\
(4.95)^{\mathrm{f}}\end{array}$ & $\begin{array}{r}30.00 \\
(7.95)^{\mathrm{e}}\end{array}$ & $\begin{array}{l}53.33 \\
(8.35)^{\mathrm{d}}\end{array}$ \\
\hline 750 & $\begin{array}{c}13.33 \\
(6.10)^{\mathrm{e}}\end{array}$ & $\begin{array}{l}36.67 \\
(8.74)^{\mathrm{e}}\end{array}$ & $\begin{array}{c}63.33 \\
(9.75)^{\mathrm{c}}\end{array}$ \\
\hline 1000 & $\begin{array}{c}16.67 \\
(7.33)^{d}\end{array}$ & $\begin{array}{c}43.33 \\
(9.27)^{\mathrm{cd}}\end{array}$ & $\begin{array}{c}80.00 \\
(10.00)^{\mathrm{c}}\end{array}$ \\
\hline 2000 & $\begin{array}{c}16.67 \\
(7.33)^{d}\end{array}$ & $\begin{array}{c}43.33 \\
(9.27)^{\mathrm{cd}}\end{array}$ & $\begin{array}{c}80.00 \\
(10.00)^{\mathrm{c}}\end{array}$ \\
\hline 4000 & $\begin{array}{c}20.00 \\
(8.05)^{\mathrm{c}}\end{array}$ & $\begin{array}{c}46.67 \\
(9.36)^{c}\end{array}$ & $\begin{array}{c}86.67 \\
(11.02)^{b}\end{array}$ \\
\hline 6000 & $\begin{array}{c}23.33 \\
(8.74)^{\mathrm{b}}\end{array}$ & $\begin{array}{c}53.33 \\
(9.88)^{\mathrm{bc}}\end{array}$ & $\begin{array}{c}96.67 \\
(11.54)^{b}\end{array}$ \\
\hline 8000 & $\begin{array}{c}26.67 \\
(9.27)^{b}\end{array}$ & $\begin{array}{c}60.00 \\
(10.34)^{b}\end{array}$ & $\begin{array}{c}100.00 \\
(18.43)^{\mathrm{a}}\end{array}$ \\
\hline 10000 & $\begin{array}{l}26.67 \\
\quad(9.27)^{\mathrm{b}}\end{array}$ & $\begin{array}{c}63.33 \\
(10.96)^{b}\end{array}$ & $\begin{array}{c}100.00 \\
(18.43)^{\mathrm{a}}\end{array}$ \\
\hline $\mathrm{AgNo}_{3}$ alone & $\begin{array}{c}0.00 \\
(0.00)^{\mathrm{h}}\end{array}$ & $\begin{array}{c}0.00 \\
(0.00)^{\mathrm{g}}\end{array}$ & $\begin{array}{c}0.00 \\
(0.00)^{f}\end{array}$ \\
\hline Soya bean seed extract & $\begin{array}{c}0.00 \\
(0.00)^{\mathrm{h}}\end{array}$ & $\begin{array}{c}0.00 \\
(0.00) \mathrm{g}\end{array}$ & $\begin{array}{c}0.00 \\
(0.00)^{\mathrm{f}}\end{array}$ \\
\hline Untreated control & $\begin{array}{c}0.00 \\
(0.00)^{\mathrm{h}}\end{array}$ & $\begin{array}{c}0.00 \\
(0.00)^{\mathrm{g}}\end{array}$ & $\begin{array}{c}0.00 \\
(0.00)^{\mathrm{f}}\end{array}$ \\
\hline $\begin{array}{c}\text { Emmamectin benzoate } \\
\text { @ } 0.2 \mathrm{~g} / 1\end{array}$ & $\begin{array}{c}80.00 \\
(16.43)^{\mathrm{a}}\end{array}$ & $\begin{array}{c}100.00 \\
(18.43)^{\mathrm{a}}\end{array}$ & $\begin{array}{l}100.00 \\
(18.43)^{\mathrm{a}}\end{array}$ \\
\hline S.Em \pm & 0.89 & 0.81 & 0.58 \\
\hline CD@1\% & 1.20 & 1.10 & 1.04 \\
\hline
\end{tabular}

Figures in the parentheses are angular transformed values.

In vertical columns, means followed by same letter do not differ significantly by DMRT $(\mathrm{P}=0.05)$ 
Table.2 Effect of Soybean based seed Green silver nanoparticles on percent larval mortality of $S$. litura (third instar)

\begin{tabular}{|c|c|c|c|c|}
\hline \multirow[b]{2}{*}{$\begin{array}{c}\text { Treatments / } \\
\text { Concentrations in } \\
\text { ppm }\end{array}$} & \multicolumn{4}{|c|}{ Hours After Treatment (HAT) } \\
\hline & 24 hours & 48 hours & 72 hours & 96 hours \\
\hline 250 & $\begin{array}{c}0.00 \\
(0.00)^{\mathrm{e}}\end{array}$ & $\begin{array}{l}10.00 \\
(4.74)^{\mathrm{e}}\end{array}$ & $\begin{array}{l}23.33 \\
(5.35)^{\mathrm{h}}\end{array}$ & $\begin{array}{l}56.67 \\
(5.95)^{\mathrm{g}}\end{array}$ \\
\hline 500 & $\begin{array}{c}0.00 \\
(0.00)^{\mathrm{e}}\end{array}$ & $\begin{array}{l}23.33 \\
6.15)^{\mathrm{d}}\end{array}$ & $\begin{array}{l}40.00 \\
(6.35)^{\mathrm{f}}\end{array}$ & $\begin{array}{c}66.80 \\
(6.05)^{\mathrm{g}}\end{array}$ \\
\hline 750 & $\begin{array}{c}10.00 \\
(4.62)^{d}\end{array}$ & $\begin{array}{l}26.67 \\
6.74)^{d}\end{array}$ & $\begin{array}{l}50.00 \\
(6.50)^{\mathrm{f}}\end{array}$ & $\begin{array}{l}75.45 \\
7.15)^{\mathrm{f}}\end{array}$ \\
\hline 1000 & $\begin{array}{l}13.33 \\
(6.54)^{\mathrm{c}}\end{array}$ & $\begin{array}{l}30.00 \\
7.15)^{\mathrm{d}}\end{array}$ & $\begin{array}{l}53.33 \\
7.45)^{\mathrm{f}}\end{array}$ & $\begin{array}{l}82.50 \\
(8.35)^{\mathrm{e}}\end{array}$ \\
\hline 2000 & $\begin{array}{c}13.33 \\
(6.54)^{\mathrm{c}}\end{array}$ & $\begin{array}{l}33.33 \\
7.95)^{\mathrm{c}}\end{array}$ & $\begin{array}{l}53.33 \\
7.45)^{\mathrm{f}}\end{array}$ & $\begin{array}{l}82.50 \\
(8.35)^{\mathrm{e}}\end{array}$ \\
\hline 4000 & $\begin{array}{c}16.67 \\
(7.33)^{b}\end{array}$ & $\begin{array}{l}36.67 \\
8.74)^{\mathrm{c}}\end{array}$ & $\begin{array}{l}56.67 \\
8.60)^{\mathrm{e}}\end{array}$ & $\begin{array}{l}85.00 \\
(9.45)^{d}\end{array}$ \\
\hline 6000 & $\begin{array}{c}16.67 \\
(7.33)^{b}\end{array}$ & $\begin{array}{l}36.67 \\
8.74)^{\mathrm{c}}\end{array}$ & $\begin{array}{l}60.00 \\
(9.30)^{d}\end{array}$ & $\begin{array}{c}87.35 \\
(10.50)^{\mathrm{c}}\end{array}$ \\
\hline 8000 & $\begin{array}{c}20.00 \\
(8.13)^{b}\end{array}$ & $\begin{array}{l}43.33 \\
9.36)^{\mathrm{b}}\end{array}$ & $\begin{array}{c}70.00 \\
(10.00)^{\mathrm{c}}\end{array}$ & $\begin{array}{c}90.00 \\
(14.75)^{\mathrm{b}}\end{array}$ \\
\hline 10000 & $\begin{array}{c}20.00 \\
(8.13)^{b}\end{array}$ & $\begin{array}{l}46.67 \\
9.88)^{b}\end{array}$ & $\begin{array}{c}76.67 \\
(11.30)^{\mathrm{b}}\end{array}$ & $\begin{array}{c}100 \\
(18.43)^{\mathrm{a}}\end{array}$ \\
\hline $\mathrm{AgNo}_{3}$ alone & $\begin{array}{c}0.00 \\
(0.00)^{\mathrm{e}}\end{array}$ & $\begin{array}{c}0.00 \\
(0.00)^{\mathrm{f}}\end{array}$ & $\begin{array}{c}0.00 \\
(0.00)^{\mathrm{i}}\end{array}$ & $\begin{array}{c}0.00 \\
(0.00)^{\mathrm{h}}\end{array}$ \\
\hline $\begin{array}{c}\text { Soya bean seed } \\
\text { extract }\end{array}$ & $\begin{array}{c}0.00 \\
(0.00)^{\mathrm{e}}\end{array}$ & $\begin{array}{c}0.00 \\
(0.00)^{\mathrm{f}}\end{array}$ & $\begin{array}{c}0.00 \\
(0.00)^{\mathrm{i}}\end{array}$ & $\begin{array}{c}0.00 \\
(0.00)^{\mathrm{h}}\end{array}$ \\
\hline Untreated control & $\begin{array}{c}0.00 \\
(0.00)^{\mathrm{e}}\end{array}$ & $\begin{array}{c}0.00 \\
(0.00)^{\mathrm{f}}\end{array}$ & $\begin{array}{c}0.00 \\
(0.00)^{\mathrm{i}}\end{array}$ & $\begin{array}{c}0.00 \\
(0.00)^{\mathrm{h}}\end{array}$ \\
\hline $\begin{array}{c}\text { Emmamectin } \\
\text { benzoate @ } 0.2 \mathrm{~g} / \mathrm{l}\end{array}$ & $\begin{array}{c}70.00 \\
(15.32)^{\mathrm{a}}\end{array}$ & $\begin{array}{c}100 \\
(18.43)^{\mathrm{a}}\end{array}$ & $\begin{array}{c}100 \\
(18.43)^{\mathrm{a}}\end{array}$ & $\begin{array}{c}100 \\
(18.43)^{\mathrm{a}}\end{array}$ \\
\hline S. Em \pm & 0.32 & 0.25 & 0.60 & 0.21 \\
\hline CD @ 1\% & 1.29 & 1.02 & 1.20 & 0.95 \\
\hline
\end{tabular}

Figures in the parentheses are angular transformed values.

In vertical columns, means followed by same letter do not differ significantly by DMRT $(\mathrm{P}=0.05)$ 
Indra kumar (2016) for the first time revealed the larvicidal activity of green nanoparticles synthesized from Carrissa carandas AgNPs, A. indica AgNPs, L. acidissima CuNps, T. peruviana AgNPs, K.K AgNPs and G. max AgNPs extracts on $5^{\text {th }}$ and $6^{\text {th }}$ instar $S$. litura larva. G. max AgNPs recorded 73.24 per cent mortality and was significantly superior to all other treatments including precursors and the plant extracts except insecticidal control. According to the Giovanni Benelli (2018) silver nanoparticles have a significant impact on insect antioxidant and detoxifying enzymes, leading to oxidative stress and cell death. Ag nanoparticles also reduced acetylcholine esterase activity, while polystyrene nanoparticles inhibited CYP450 isoenzymes resulting in larval death.

The present study is also in line with Jyothsna and Usha Rani (2015) who observed that Silver nanoparticle treatments decreased body weights of S.litura third instar larvae. Treatments affected the activity of detoxifying enzymes. Oxidative stress induced in larval guts was countered by enhanced antioxidant enzyme which leads to prolonged development period of instars as being observed in the present study.

The present findings are in agreement with Chakravarthy et al., (2012a) who used synthetic nanoparticles of CdS, Nano-Ag and Nano-TiO2 against S. litura. Nano Ag caused maximum (56.89\%) mortality at $2400 \mathrm{ppm}$ followed by 46.89 and 33.44 per cent mortality at 1200 and 600 ppm respectively. This more or less confirms the present finding in which $8000 \mathrm{ppm}$ recorded cent percent mortality in $2^{\text {nd }}$ instar larva at 72 HAT and $10000 \mathrm{ppm}$ recorded cent per cent mortality in $3^{\text {rd }}$ instar larva at 96 HAT. Further, the present study is also comparable with Chakravarthy et al., (2012b) who tested the DNA tagged gold nanoparticles against S.litura at 200, 300, 400 and 500 ppm against second instar S. litura larvae exposed to each concentration of DNA tagged gold nanoparticles for 30 seconds causing 50 per cent larval mortality above $500 \mathrm{ppm}$. As the particle concentration and days after treatment increased, larval mortality also increased and is in full confirmation with the present finding though the nanoparticles used is Silver.

It is concluded in the present study soya seed based AgNp were synthesized through sun light exposure method. soyabean seed extract was acts as both reducing and stabilizing agent for AgNp. The per cent mortality was highest $(100 \%)$ at 72 hours and 96 hours after treatment for $2^{\text {nd }}$ and $3^{\text {rd }}$ insta respectively. Increased concentration and exposure hours increased mortality. The soya seed based green Nano AgNps provides a promising novel approach for the large-scale industrial production of nanonmaterial's for pest management against $2^{\text {nd }}$ and $3^{\text {rd }}$ instars of S.litura.

\section{References}

Ayano H., Miyake M, Terasawa K, Kuroda M, Soda S, Sakaguchi T, Ike M (2014) Isolation of a selenite-reducing and cadmium-resistant bacterium

Pseudomonas sp. strain RB for microbial synthesis of $\mathrm{CdSe}$ nanoparticles. J Biosci Bioeng 117(5): 576-581

Chakravarthy, A. K., Chandhrashekharaiah, Subhash, B. K., Bhattacharya, A., Dhanabala, K., Gurunatha, K. and Ramesh, P., 2012a, Bio efficacy of inorganic nanoparticles $\mathrm{CdS}$, Nano-Ag and $\mathrm{Nano}_{-} \mathrm{TiO}_{2}$ against Spodoptera litura (Fabricius) (Lepidoptera: Noctuidae). Curr. Biotica, 6 (3): 271281.

Chakravarthy, A. K., Bhattacharya, A., Shashank, P. R., Timothy, T. E., Doddabasappa, B. and Swapan, K. M., 
2012b, DNA-tagged nano gold a new tool for the control of the armyworm, Spodoptera litura Fab. (Lepidoptera: Noctuidae). African J. Biotechnol., 11 (38): 9295-9301.

Benelli, G., 2018. Mode of action of nanoparticles against insects. Environ Sci Pollut Res 25:12329-12341

Indrakumar Naik., 2015. Effect of green nanoparticles on Spodoptera litura (Fabricius) and Bombyx mori (Linnaeus) M. Sc. (Agri) Thesis, Uni. Agri. Sci., Dharwad 58005 (India).85108

Jha A K, Prasad K (2012) Banana fly (Drosophila sp.) synthesizes CdS nanoparticles. J Bionanosci 6(2):99-103

Jyothsna, Y and Usha Rani P., 2015. Lepidopteran insect susceptibility to silver nanoparticles and measurement of changes in their growth, development and physiology. Chemosphere 124: 92102

Kasmara, H., Melanie, Nurfajri, D. A., Hermawan, W., and Panatarani, C. 2017, February. The toxicity evaluation of prepared Lantana camara nano extract against Spodoptera litura (Lepidoptera: Noctuidae). AIP Conference Proceedings (Vol. 1927, No. 1, p. 030046). AIP Publishing. Kranthi, K. R., Jadhav, D. R., Kranthi, S., Wanjari, R. R., Ali, S. S. and Russell, D. A., 2002, Insecticide resistance in five major insect pests of cotton in India. Crop Prot., 21: 449-460.

Prasad, P., V., 2014, soybean seeds extract based green synthesis of silver nanoparticles. Indian J. Adv. Chem. Sci., 2(3): 208-211.

Srikanth, H. N., Nargund, V. B., Patil, R. R. and Naik, S. T., 2017, Microwave assisted synthesis of green silver nanoparticles (AgNPs) using extract of pomegranate peel and their antifungal activity. Proc. Nation. Symp. Emerging trends plant health Mgmt. Relation Climate Change, 12-13, September, Coll. Hort. Bengaluru (India), p. 113

Sudhakaran, R., 2002. Efficacy of lufenuron (Match 5\% EC) against Spodoptera litura under in vitro condition. Insect Environ., 8: 47-48.

\section{How to cite this article:}

Goutam B. Hosamani, R.R. Patil, V.I. Benagi, S.S. Chandrashekhar and Nandihali, B.S. 2019. Synthesis of Green Silver Nanoparticles from Soybean Seed and its Bioefficacy on Spodoptera litura (F.). Int.J.Curr.Microbiol.App.Sci. 8(09): 610-618. doi: https://doi.org/10.20546/ijcmas.2019.809.073 